\title{
Embedding Digital Capability into the Higher Education Curriculum: The Case of Ghana
}

\author{
Justice Kofi Armah", Duan Van Der Westhuizen \\ Department of Science and Technology Education, University of Johannesburg, South Africa
}

Received October 8, 2019; Revised November 30, 2019, Accepted December 4, 2019

Copyright $\subseteq 2020$ by authors, all rights reserved. Authors agree that this article remains permanently open access under the terms of the Creative Commons Attribution License 4.0 International License

\begin{abstract}
In this paper, we report on the digital experiences of students at a dual-mode, higher education institution in Ghana. Recognizing the role of digital technologies in an increasingly globalized and competitive economy, Ghanaian authorities have embarked on several initiatives to support the development of the digital skills and capabilities of its students to enhance learning and to improve their employability in the job market. However, evidence exists that despite these initiatives and the massive investment into digital skills development, students in Ghana are still grappling with the acquisition of the skills needed for the workplace of the $21^{\text {st }}$ century. The question thus arises whether Ghanaian higher education institutions (HEIs) are sufficiently developing the digital capabilities of their students. This study used the 'Digital at course level' dimension of the Joint Information Systems Committee (JISC) - UK Digital Experience Insight Survey to determine the digital experiences of students in their chosen academic discipline to prepare them for their careers. Census sampling targeted all final-year students at a selected higher education institution. The online survey reached 14,286 students and 800 students (5.6\%) responded. The results show that students use personal devices to support learning outside the classroom, despite limited attempts to embed the development of digital skills into academic disciplines. Therefore, digital technologies are rarely used to communicate and collaborate, to solve problems or to create digital artefacts in the classroom. The findings also revealed that gender and mode of study did not influence the students' digital experiences. The limitation of the study is that the results for only one institution are reported.
\end{abstract}

Keywords Digital Capabilities, Digital Technologies, Ghana Higher Education, Digital Learning, Digital Integration

\section{Introduction}

The accelerating pace at which digital technology is transforming the workplace directly impacts the skill requirements for modern jobs. Technologies such as artificial intelligence, the 'internet of things', robotics, big data as well as virtual and augmented reality may gradually replace most of today's routine jobs [1]. As a result, future graduates need to 'up-skill' and 'up-tool' if they wish to remain relevant in the workplace [2].

The need for students to develop digital capabilities is more important than ever as the ecosystems of business are changing [3]. Therefore, the challenge remains for governments, employers, policymakers, educators and students alike to identify the digital skills that are relevant not only for today but which will also meet the demands of the workplace of the future. It is incumbent on higher education institutions (HEIs) that produce the workforce of a country to rethink the preparation of students to meet the challenges of a rapidly changing digital society. The research question that this paper responds to is: What are the digital experiences of students at a HEI in Ghana considering the 'digital at course level' dimension of the JISC Digital Experience Insight Survey.

Despite the demands of industry, a recent report by the House of Commons (HOC) indicates that graduates still have insufficient digital skills to be successful in the workplace [4]. For most students, HEIs are the only place to experience and develop such digital skills and competencies [5]. However, educators often overestimate students' digital capabilities and ignore developing these in the academic context [6, 7]. This threatens the employability of the graduates and undermines competitiveness in the globalized digital society. As HEIs are mandated to train students for the global job market, it is imperative that they employ the appropriate digital technologies at course level to develop students' digital capabilities and understanding of the modern workplace [8]. 
While the HEIs in Ghana acknowledge the importance of developing digital capabilities of students through the introduction of institution-wide digital strategies, it is still not known how students experience these technologies while studying for their chosen career and whether or not their experiences prepare them for the digital workplace. Graduates from Ghanaian HEIs seem to lack the necessary skills to be effective team players in the digital workplace [9]. This study therefore seeks to understand, from a student perspective, what their experiences are with digital technology as part of their courses. This will provide HEIs with valuable insights into elements of digital technology in their curriculum.

To illustrate this, we will briefly outline the digital technologies students use to support their learning. Next, we examine the concept of digital capability development. We emphasize that it is particularly important for developing countries like Ghana to develop digitally capable students. We then describe the research methods that were used to survey students in the dual-mode HEI, using the Joint Information Systems Committee 'Digital Tracker' tool. Thereafter, the results of the survey are reported. Lastly, recommendations are made for student digital capability development.

\section{Literature}

Research indicates that "digital literacy is developed on a set of technology-based practices which begin from access to technology and functional skills to higher-level capabilities" [10]. Moreover, digital skills are subject-specialized. Therefore, the adoption of tools and skills for learning should be highly dependent on the tasks that students engage with [10]. The next section discusses the students' use of digital technology to support their learning outside the classroom. Next, the concept of digital integration in the learning environment is expatiated.

\subsection{Students' Use of Personal Devices for Learning outside the Classroom}

Students' access to and use of personal devices in the learning environment is reconfiguring the relationships between public and private spaces [11]. However, research indicates that students' use of digital technology in an academic context is widespread but not deep. They (students) are particularly interested in expanding the use of a few specific technologies [12].

In the digital learning environment, students use their personal devices to create learning resources, access lecture notes, manage links or references, play games, organise study time, record lectures, watch movies or listen to materials. They use their digital devices to discuss, share ideas and learning resources informally on social media sites. It is also evident that they prefer to use their devices to link with core academic and extra-curricular activities [13].

In an OECD 2014 report, it was found that, more than half $(51.3 \%)$ of the students in OECD countries used their own digital devices outside the classroom for academic purposes, such as searching for information or completing and submitting assignments [14]. This figure rose to 67\% in 2015 [15]. Smartphones are the most commonly owned devices, however, laptops are the tools used most often to support studies, far exceeding other devices [13]. Students cite reasons such as small screen, battery life and data cost as barriers to the use of smartphones to support learning [16].

A recent report by the 'EDUCAUSE Centre for Academic Research' (ECAR) also identified laptops to be the dominant devices used by students in the US. According to the study, students find laptops to be extremely important, followed by smartphone usage, with tablet and desktop use for learning on the decline in recent years [17]. Similarly, a JISC study which involved over 21,095 students from Australia and New Zealand revealed that almost $95 \%$ of higher education students in the two countries owned and used laptops to support their learning. About $81.3 \%$ of them used their smartphones to support their learning outside the classroom with only a minority using tablets or desktops [8].

The reality of students' use of digital technology to support learning is complex in developing countries. For instance, a study in sub-Saharan Africa indicated that the use of digital technologies for learning is encouraging, with South Africa emerging as the leader. The study reports usage to a less extent among students in some urban areas of Ghana and Malawi [18]. Though some students in Ghana use their devices to aid personal learning [19, 20], others indicated that they did not have sufficient knowledge and skills to use these tools for academic purposes. Other studies suggest that although many students hold basic digital proficiency skills, they are unable to employ these skills in general university learning $[22,23]$. Only a handful of students $(37 \%)$ are able to use digital technologies to communicate effectively in a digital environment [23]. The study continued that $25.3 \%$ of the students have never used the internet for collaboration with a group or a team. HEIs cannot ignore the potential of technology in the personal lives of students. They need to provide and embrace these technologies in teaching and learning if they want to engage students and make meaningful connections.

\subsection{Conceptualizing Digital Integration}

Within the curriculum, it is the responsibility of educators to identify opportunities that allow students to use their personal devices and resources to look for information, collaborate, communicate, think critically, create digital artefacts and solve authentic problems. 
Digital activities should challenge students to an appropriate degree of creativity [24]. There are several approaches on how to integrate digital skills into the curriculum. At present, most universities develop students' digital literacies using compulsory ICT courses and cross-cutting, subject-related ICT teaching as a means to this end $[23,9]$. These universities teach ICT competencies (such as 'office software' and Internet skills) in specific ICT courses in computer venues and assess these competencies through ICT tests / exams [25]. However, it is argued that digital literacy is not functional operations to be dissected into smaller, self-contained skills such as searching for information, creating a presentation, word processing or editing audio-visuals to be taught in the classroom. Nor is digital literacy a generic skill that can be readily implemented in different practices or activities [23]. Students need to experience, practice and develop digital capability skills through scaffolding, as an integral component of academic learning activities, within various subject areas and domains, rather than these capabilities being treated as generic skills to be taught as separate modules/units.

The best method to allow students to experience new technologies and develop their capabilities is to embed these technologies and skills in the context of the academic curriculum [26]. The curriculum is the best route to highlight and develop digital practices [10]. This is because the curriculum is the focus of students' attention and a key driver of effort [27]. For example, within the curriculum, educators can set tasks that draw on digital practices such as shaping a presentation, portfolios and workshops around digital literacies, designing authentic activities that require the use of technology. It is therefore important that digital skills be situated within a professional and academic context and influenced by a wide range of practices such as digital collaboration, searching for information and the creation of portfolios [10].

Other researches confirm that the curriculum is the 'lived experience' that students draw on to make sense of the world [28]. Embedding digital capability into the curriculum fosters collaborative relationships among students and reduces the amount of time student pull out of the learning environment to seek remedial instruction such as digital proficiency skills outside the learning environment. When digital technologies are embedded in the context of the academic curriculum, this also enables the students to move seamlessly between the individual, partner, small group and whole-class instruction to broaden, challenge or affirm their thinking [28]. Digital technology (tools and skills) at course level could provide students with authentic audiences with whom to share their learning across a variety of modes. It is therefore the responsibility of educators to provide opportunities for students to develop enquiry projects that link their interests and academic skills with a digital platform. This will encourage students to closely examine issues that are important to them while learning to make real-world connections to what they are learning. Students will be able to tweet and blog their work and invite comments or questions from the online audience (peers and experts). The comments or questions from followers will help prompt the students to alter projects or receive support for their projects whilst developing emotional intelligence and problem-solving skills [28].

\subsection{Purpose of the Study}

The purpose of this study is to understand students' experiences with their own digital technology outside the learning environment and at course level in a leading dual-mode university in Ghana through descriptive studies.

\subsection{Research Questions}

1. What are personal digital devices that students have to support their learning outside the learning environment?

2. To what extent do students experience digital activities at course level?

3. Is there any difference in students' experiences of digital activities at course level?

\section{Methodology}

\subsection{Research Design}

The study utilized a descriptive quantitative research design to understand students' use of digital devices to support learning outside the classroom and their experiences of digital technology at course level in a leading dual-mode HEI in Ghana.

\subsection{Settings and Participants}

A dual-mode HEI in Ghana was targeted and 'census sampling' was used to identify all final-year undergraduate and postgraduate students. The total population was 14,286. In all, 800 students, representing $6.0 \%$ of the total population, responded to the survey. This population was targeted as they would have had the longest enrolment at the institution and would be in the best position to accurately report on the digital capability development efforts of the institution. The age of the respondents ranged from 19 to 62 (mean age $=27.5, \mathrm{SD}=6.001$ ). Age was non-normally distributed, with skewness of 1.87 ( $\mathrm{SE}=$ $0.05)$ and Kurtosis of $3.93(\mathrm{SE}=0.10)$. The average age of the distance learners was 32 while the average of full-time students was 24. Table 1 displays the disaggregated frequency analysis of the sample by gender, level of study, field of study and mode of study. There was a low representation of female students (35.4\%) in comparison with the national average of 51\% (Ghana Statistical Service, 
2016). Full-time students provided $52.4 \%$ of the responses.

Table 1. Profile of learners

\begin{tabular}{|c|c|c|c|}
\hline & Male & N & $\%$ \\
\hline Gender & Female & 517 & 64.6 \\
\hline $\begin{array}{c}\text { Level of } \\
\text { study }\end{array}$ & Graduate & 283 & 35.4 \\
\hline $\begin{array}{c}\text { Field of } \\
\text { study }\end{array}$ & Final Year Undergrad & 119 & 14.9 \\
\hline & Agriculture & 37 & 85.1 \\
\hline & Biological and Biomedical & 36 & 4.5 \\
\hline & Business & 269 & 34.9 \\
\hline & Communication and Journalism & 32 & 4.0 \\
\hline & Computer Science & 28 & 3.5 \\
\hline & Education & 158 & 19.8 \\
\hline & Liberal Studies & 41 & 5.1 \\
\hline & Medical and Health Professions & 40 & 5.0 \\
\hline & Physical Sciences & 23 & 2.9 \\
\hline & Psychology & 98 & 12.3 \\
\hline Mode of & Distance Student & 381 & 47.6 \\
\hline & Full-time Student & 419 & 52.4 \\
\hline
\end{tabular}

\subsection{Instrument}

This study used the JISC 'Digital Tracker' survey instrument to establish the extent to which the development of the digital capabilities of students in HEIs is embedded in the teaching of academic disciplines. The Digital Tracker instrument (https://www.jisc.ac.uk/rd/projects/student-digital-experie nce-tracker) was deemed appropriate to address the aims of this study. The instrument uses four dimensions, aptly labelled "digital lives of learners, digital at the university, digital at course level, and students' attitude to digital" [8]. The 'digital at course level' dimension of the survey was selected to report on. The questionnaire also drew items from the 'digital lives of learners' dimension of the survey.

The 'digital at course level' dimension comprises multiple-choice questions that require responses to three-point Likert-type scale options with 'weekly or more' at the high end of the scale and 'never' at the lowest end [29]. JISC validated the instrument by piloting it among 22,000 higher and further education students in 72 institutions in the UK and 5,000 students in ten international institutions [13].

The questionnaire was piloted among 30 undergraduates' students at a comparable higher education institution in Ghana to determine the extent to which the items made sense for Ghanaian students and how easy they found completing the survey [30]. As no issues were reported, it was not necessary to make any amendments to the final instrument. The primary interest of Digital Tracker was to capture the experiences of students about mutually exclusive issues around the digital learning environment. Hence the scale developed was 'Likert item' and not 'Likert scale'. We therefore derived composite variables (cluster Likert items) out of the Likert items in the survey [31]. To do this, composite scores were computed using exploratory factor analysis (EFA). The EFA yielded an eigenvalue of 2.431 , explaining $5.9 \%$ of the total variance. Cronbach's alpha coefficient was applied, yielding a result of 0.779 , which shows an acceptable inter-item correlation.

\subsection{Data Collection}

Data was collected online using JISC's 'Online Surveys' formerly Bristol Online System (BOS). The survey reached 13,364 students, with 800 students $(6 \%)$ responding. We sent the respondents emails through the university's email system telling them about the survey. The content of the email included a hyperlink to the survey website, which the respondents need to click to open the questionnaire for participation. Upon completion, the respondents simply clicked a button to submit their responses to the 'Online Surveys' database. The responses were kept in the database for analysis. Data was collected over a period of three months.

\subsection{Data Analysis}

The data was analysed using the 'Online Survey' tool that automatically calculated basic descriptive statistics and presented data visually as tables. In addition, SPSS version 25 was used to perform other statistical analyses. The two-way ANOVA statistical test tool was used to determine whether inferential relationships existed between the students depending on mode of study (for example, digital experiences of distance students' vs. full-time students at the university).

\section{Results}

In the following sections, the results of the survey are presented as they relate to the items that were included in the Digital Tracker and the objectives of the research.

\subsection{Personal Device Used by Students to Support Their Own Learning outside the Classroom}

Earlier studies indicate that students use their digital devices to support learning. This involved the discussion of learning informally on social media, looking for additional resources not recommended by the lecturer and organizing study time. The questionnaire probed the types of digital devices owned by students to support their learning. The tools listed were desktop computer, laptop computer, tablet / iPad, smartphone and printer. Table 2 displays the results for this item. 
Table 2. Distribution of tools used by students to support their learning

\begin{tabular}{|c|c|c|c|c|}
\hline \multirow{2}{*}{\multicolumn{2}{|c|}{}} & Responses & Responses & \multirow{2}{*}{ Percent of Cases } \\
\cline { 2 - 5 } & & $\mathrm{N}$ & $\mathrm{N}$ & \multirow{2}{*}{$11.4 \%$} \\
\hline \multirow{3}{*}{ Digital tools used by students to support their learning a } & Desktop computer & 91 & $6.3 \%$ & $63.9 \%$ \\
\cline { 2 - 5 } & Laptop computer & 511 & $35.5 \%$ & $19.5 \%$ \\
\cline { 2 - 5 } & Tablet/iPad & 156 & $10.8 \%$ & $76.3 \%$ \\
\cline { 2 - 5 } & Smartphone & 610 & $42.3 \%$ & $9.1 \%$ \\
\cline { 2 - 5 } & Printer & 73 & $5.1 \%$ & 9 \\
\hline
\end{tabular}

a. Dichotomy group tabulated at value 1 .

From Table 2, it is apparent that students use their digital devices to support their independent learning. Smartphones are the most frequently used device used by students to support learning (76.3\%), followed by laptop computers $(63.9 \%)$. Printers were the devices least used by students to support their learning.

The data was further disaggregated according to gender and mode of study. The data summarized in Table 3 shows that both male and female students perceived digital technologies as valuable in supporting their learning outside the classroom. Slightly more male students (76.9\%) used a smartphone to support their study than female students $(75.6 \%)$. Furthermore, female students $(65.1 \%)$ were more likely to use their laptops to support learning outside the classroom compared to their male counterparts $(62.7 \%)$. Similarly, female students $(12.2 \%)$ owned more printers than males $(6.0 \%)$.

Table 3. Distribution of tools used by students to support learning by gender

\begin{tabular}{|c|c|c|c|c|}
\hline \multicolumn{2}{|c|}{} & \multicolumn{2}{|c|}{ Gender } & \multirow{2}{*}{ Total } \\
\cline { 2 - 5 } \multicolumn{2}{|c|}{} & Male & Female & \\
\hline \multirow{3}{*}{ Desktop computer } & Count & 49 & 42 & \multirow{2}{*}{91} \\
\cline { 2 - 5 } & \% within Q2 & $12.3 \%$ & $10.5 \%$ & \\
\hline \multirow{3}{*}{ Laptop computer } & Count & 250 & 261 & 511 \\
\cline { 2 - 5 } & \% within Q2 & $62.7 \%$ & $65.1 \%$ & \\
\hline \multirow{2}{*}{ Tablet/iPad } & Count & 80 & 76 & 156 \\
\cline { 2 - 5 } & \% within Q2 & $20.1 \%$ & $19.0 \%$ & \\
\hline \multirow{2}{*}{ Smartphone } & Count & 307 & 303 & 610 \\
\cline { 2 - 5 } & \% within Q2 & $76.9 \%$ & $75.6 \%$ & \\
\hline \multirow{2}{*}{ Printer } & Count & 24 & 49 & 73 \\
\cline { 2 - 5 } & \% within Q2 & $6.0 \%$ & $12.2 \%$ & \\
\hline Total & Count & 399 & 401 & 800 \\
\hline
\end{tabular}

Percentages and totals are based on respondents.

a. Dichotomy group tabulated at value 1 .

In terms of mode of study, Table 4 shows a disparity in students' ownership of digital devices to support learning outside the classroom. Of note is that an overwhelming percentage of full-time students $(82.1 \%)$ owned smartphones that they used to support their learning outside the classroom compared to distance learners
(69.7\%). Similarly, the full-time students were more likely to own laptops $(80.7 \%)$ than the distance learners (45.1\%). However, the use of their own printers to support learning was greater among distance learners (10.8\%) compared to the full-time students.

Table 4. Distribution of students according to digital tools

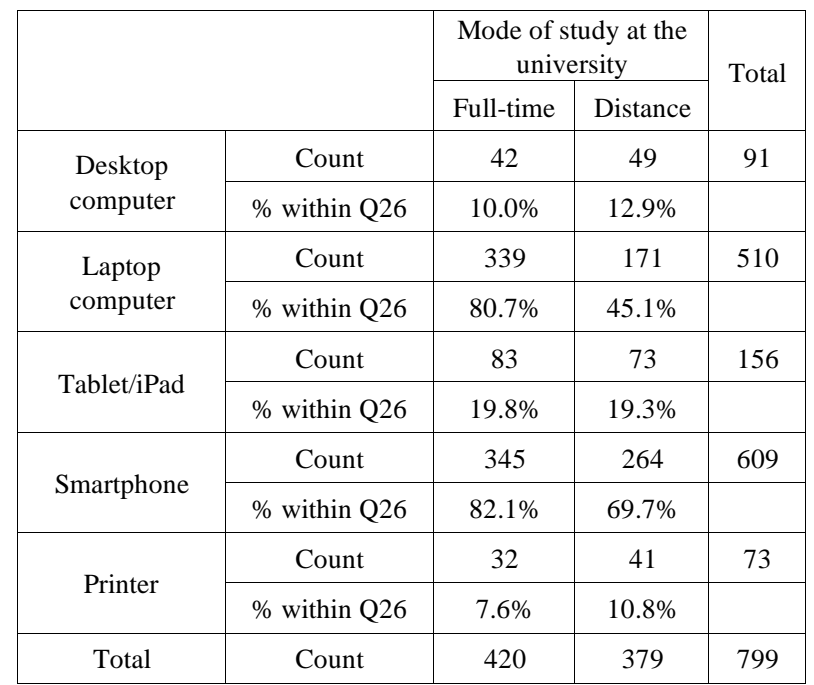

Percentages and totals are based on respondents.

Dichotomy group tabulated at value 1 .

\subsection{Students' Experiences of Digital Technology at Course Level}

The research question aimed to determine the digital activities students experienced most in their course. The percentage of students agreeing to use a digital device to find information online was substantially higher than all other activities. From Table 5, it can be seen that about $47.3 \%$ of the students had never used a polling device or online quiz to give answers in class. About half of the respondents $(49.1 \%)$ said they had never used digital devices in class to create a digital record/portfolio of their learning while $42.3 \%$ confirmed that they had never produced work in digital format other than Word/PowerPoint. 
Table 5. Digital activities at course level

\begin{tabular}{|l|c|c|c|}
\hline & Never & $\begin{array}{c}\text { Monthly } \\
\text { or less }\end{array}$ & $\begin{array}{c}\text { Weekly or } \\
\text { more }\end{array}$ \\
\hline Find information online & $10.5 \%$ & $19.2 \%$ & $70.3 \%$ \\
\hline Work online with others & $31.9 \%$ & $34.0 \%$ & $34.1 \%$ \\
\hline $\begin{array}{l}\text { Use an educational game or } \\
\text { simulation for learning }\end{array}$ & $41.5 \%$ & $30.8 \%$ & $27.7 \%$ \\
\hline $\begin{array}{l}\text { Use a polling device or } \\
\text { online quiz to give answers } \\
\text { in class }\end{array}$ & $47.3 \%$ & $29.4 \%$ & $23.3 \%$ \\
\hline $\begin{array}{l}\text { Create a digital record / } \\
\text { portfolio of learning }\end{array}$ & $49.1 \%$ & $28.4 \%$ & $22.5 \%$ \\
\hline $\begin{array}{l}\text { Produce work in digital } \\
\text { formats other than Word / } \\
\text { PowerPoint }\end{array}$ & $42.3 \%$ & $31.9 \%$ & $25.8 \%$ \\
\hline
\end{tabular}

Table 6 shows that female students were more likely to experience digital technology at course level than male students. For instance, female students $(72 \%)$ used digital technology to find information in class more than male students $(68.6 \%)$. More female students $(35.3 \%)$ worked online with fellow students at course level than male students $(32.9 \%)$. The majority of the students [Female: 47.7\%; Male: $46.9 \%$ ] had never used a polling device or online quiz to give answers in class. A similar percentage of female students and male students had never created a digital record/portfolio of their work in class. Some $41.2 \%$ of female students said they had never produced work in digital formats other than Word/PowerPoint, as compared to $43.5 \%$ of male students.

Table 7 shows the data disaggregation of students' experience of digital activities in a course by mode of study. It shows that $77.8 \%$ of the full-time students found information online weekly or more, compared to $62 \%$ of distance learners. The full-time students (29.1\%) also produced work in a digital format more on a weekly basis than distance learners $(22.1 \%)$. However, more distance learners $(25.1 \%)$ used a polling device or online quiz to give answers than full-time students (21.8\%). The majority of distance learners $(37.4 \%)$ used a digital device weekly or more to work online with others online, compared to $31 \%$ for full-time students. There were not many differences between the two groups in the case of students' use of digital devices to produce work other than through Word/PowerPoint weekly or more.

Table 6. Digital activities at course level according to gender

\begin{tabular}{|l|c|c|c|c|c|c|}
\hline & \multicolumn{3}{|c|}{ Male } & & \multicolumn{3}{c|}{ Female } \\
\hline & Never & $\begin{array}{c}\text { Monthly or } \\
\text { less }\end{array}$ & $\begin{array}{c}\text { Weekly or } \\
\text { more }\end{array}$ & Never & $\begin{array}{c}\text { Monthly or } \\
\text { less }\end{array}$ & $\begin{array}{c}\text { Weekly or } \\
\text { more }\end{array}$ \\
\hline Find information online & 11.8 & 19.6 & 68.6 & 9.3 & 18.8 & 72.0 \\
\hline Work online with others & 33.4 & 33.7 & 32.9 & 30.3 & 34.3 & 35.3 \\
\hline $\begin{array}{l}\text { Use an educational game or simulation for } \\
\text { learning }\end{array}$ & 39.2 & 33.2 & 27.6 & 43.8 & 28.5 & 27.7 \\
\hline $\begin{array}{l}\text { Use a polling device or online quiz to give } \\
\text { answers in class }\end{array}$ & 46.9 & 31.8 & 21.3 & 47.7 & 26.9 & 25.4 \\
\hline Create a digital record / portfolio of learning & 49.7 & 30.1 & 20.2 & 48.5 & 26.8 & 24.8 \\
\hline $\begin{array}{l}\text { Produce work in digital formats other than } \\
\text { Word/PowerPoint }\end{array}$ & 43.5 & 31.9 & 24.6 & 41.2 & 31.9 & 26.9 \\
\hline
\end{tabular}

Table 7. Digital activities at course level by mode of study

\begin{tabular}{|l|c|c|c|c|c|c|}
\hline & \multicolumn{3}{|c|}{ Full-time students } & \multicolumn{3}{c|}{ Distance students } \\
\hline & Never & $\begin{array}{c}\text { Monthly or } \\
\text { less }\end{array}$ & $\begin{array}{c}\text { Weekly or } \\
\text { more }\end{array}$ & Never & $\begin{array}{c}\text { Monthly or } \\
\text { less }\end{array}$ & $\begin{array}{c}\text { Weekly or } \\
\text { more }\end{array}$ \\
\hline Find information online & 4.3 & 17.9 & 77.8 & 17.2 & 20.6 & 62.3 \\
\hline Work online with others & 32.2 & 36.8 & 31.0 & 31.6 & 31.0 & 37.4 \\
\hline $\begin{array}{l}\text { Use an educational game or simulation } \\
\text { for learning }\end{array}$ & 40.8 & 33.2 & 26.0 & 42.4 & 28.0 & 29.6 \\
\hline $\begin{array}{l}\text { Use a polling device or online quiz to } \\
\text { give answers in class }\end{array}$ & 44.3 & 34.0 & 21.8 & 50.5 & 24.3 & 25.1 \\
\hline $\begin{array}{l}\text { Create a digital record / portfolio of } \\
\text { learning }\end{array}$ & 49.2 & 29.3 & 21.6 & 49.2 & 27.2 & 23.5 \\
\hline $\begin{array}{l}\text { Produce work in digital formats other } \\
\text { than Word/PowerPoint }\end{array}$ & 37.7 & 33.2 & 29.1 & 47.3 & 30.6 & 22.1 \\
\hline
\end{tabular}




\subsection{Difference in Students' Experiences of Digital Activities at Course Level}

This question sought to establish the difference in students' response to their experiences with digital technology at course level. This was to determine whether gender or mode of study had an effect on the students' experiences with digital technology. Table 8 provides the descriptive statistics (mean and standard deviation) for each combination of the groups of the independent variables (gender and mode of study).

Table 8. Descriptive statistics for gender and mode of study

\begin{tabular}{|c|c|c|c|c|}
\hline \multicolumn{5}{|c|}{ Dependent Variable: Digital activities at course level } \\
\hline \multirow{3}{*}{ Gender } & Mode of study at the university & Mean & Std. Deviation & $\mathrm{N}$ \\
\hline \multirow{3}{*}{ Male } & Full-time student & 2.0115 & .52347 & 231 \\
\cline { 2 - 5 } & Distance learner & 1.8601 & .62386 & 162 \\
\cline { 2 - 5 } & Total & 1.9491 & .57114 & 393 \\
\hline \multirow{3}{*}{ Female } & Full-time student & 1.9810 & .53286 & 184 \\
\cline { 2 - 5 } & Distance learner & 1.9888 & .61702 & 208 \\
\cline { 2 - 5 } & Total & 1.9851 & .57833 & 392 \\
\hline \multirow{3}{*}{ Total } & Full-time student & 1.9980 & .52723 & 415 \\
\cline { 2 - 5 } & Distance learner & 1.9324 & .62247 & 370 \\
\cline { 2 - 5 } & Total & 1.9671 & .57466 & 785 \\
\hline
\end{tabular}

A two-way ANOVA was conducted that examined the effect of gender and mode of study on the students' digital experiences. The results are shown in Table 9. There was no statistically significant interaction between the effects of gender and mode of study on the students' digital experiences $-\mathrm{F}(1,781)=3.724, \mathrm{p}=.054$.

Table 9. Tests of between-subject effects

\begin{tabular}{|c|c|c|c|c|c|}
\hline \multicolumn{7}{|c|}{ Dependent Variable: digital at course level } \\
\hline Source & Type III Sum of Squares & df & Mean Square & F & Sig. \\
\hline Corrected Model & $2.445^{\text {a }}$ & 3 & .815 & 2.482 & .060 \\
\hline Intercept & 2964.057 & 1 & 2964.057 & 9026.646 & .000 \\
\hline Q2 & .464 & 1 & .464 & 1.414 & .235 \\
\hline Q26 & .995 & 1 & .995 & 3.030 & .082 \\
\hline Q2 $* 26$ & 1.223 & 1 & 1.223 & 3.724 & .054 \\
\hline Error & 256.455 & 781 & .328 & & \\
\hline Total & 3296.417 & 785 & & & \\
\hline Corrected Total & 258.900 & 784 & & & \\
\hline
\end{tabular}




\section{Discussions and Conclusions}

This paper explored higher education students' experiences with digital technology in the context of their academic curriculum. While notions of digital literacy are rapidly evolving, this study presents the reality of what is happening on the ground in a leading higher education institution in Ghana. Firstly, the study focused on the tools that students have already owned to support their learning outside the classroom. It was concluded that students owned digital devices which they used to support their learning outside the classroom environment. The most common digital device used by students was smartphones, followed by laptops. Female students owned more personal laptops than male students. They also owned more printers, which they used to support their independent learning. Students who studied full-time owned more digital devices such as smartphones and laptops, which they used to support their learning. The distance learners used more desktop computers and printers in their independent study but this was in small percentages. The findings concerning digital devices used most to support learning ran counter to the literature. Earlier reports suggest that laptops are the most commonly used digital device to support independent learning $[8,17]$. The result may be due to the fact that students in Ghana are less likely to afford laptops due to their socio-economic background compared to their counterparts in the US and the UK.

Next, students' experiences with digital technologies (activities) at course level were examined. It was found that the most frequent activity was the use of digital technology to search for information online. Interacting with fellow students was found to be the next important activity that students experienced weekly more in their subject discipline. However, this was on a lower basis. Only about a third of the students interacted with their fellow students online to discuss learning at course level. About half of the students had never used digital tools such as polling devices or online quizzes to give answers in class. Similarly, the majority of the students opined that they had never created a digital record/portfolio of their learning. This result corroborates that of [23] who in 2012 reported that more than half of students from Ghana have never experienced digital collaboration in an academic context. It also supports the premise that the use of digital technology for learning among students in Ghana is not deep;hence students will need more support from lecturers to develop their digital skills in the context of their academic disciplines [12, 32].

Finally, it was found that neither gender nor mode of study had any significant effect on students' digital experiences at the course level. These findings support an earlier study by Anane-Boakye [32] who suggests that students in Ghana, irrespective of their gender or mode of study, experienced minimal digital skills or support in the academic context [21,32].
Students own and use digital devices to support their learning outside the learning environment. However, the findings of this study reveal that their experiences with technology in their subject discipline are low. Higher education institutions in Ghana should therefore direct greater efforts at mapping digital skills into the academic curriculum to develop students' digital capabilities in the context of their chosen career to better prepare students for the digital economy. In particular, lecturers should identify practical skills within the curriculum and set authentic tasks that draw on those skills. This will allow students to use their devices to create digital artefacts and practice critical skills such as digital communication, digital collaboration, critical thinking and problem-solving.

\section{REFERENCES}

[1] Fadel, C., Bialik, M., \& Trilling, B. (2015). Four-Dimensional Education: The competencies learners need to succeed. Center for Curriculum Redesign.

[2] Chui, M., Manyika, J., \& Miremadi, M. (2015). Four fundamentals of workplace automation. McKinsey Quarterly, 29(3), 1-9.

[3] World Economy Forum (2016). The Future of Jobs Employment, Skills and Workforce Strategy for the Fourth Industrial Revolution, Online available from: http://www3. weforum.org/docs/WEF_Future_of_Jobs.pdf.

[4] House of Commons. (2016). Science and Technology Committee: Digital skills crisis: second report of Session 2016-17: report, together with formal minutes relating to the report: (pp. 3-32). London: House of Commons. Retrieved from https://publications.parliament.uk/pa/cm20 1617/cmselect/cmsctech/270/270.pdf

[5] OECD. Education: Korea tops new OECD PISA survey of digital literacy, Online available from: http://www.oecd.or $\mathrm{g} /$ hungary/educationkoreatopsnewoecdpisasurveyofdigitall iteracy.htm, 2009.

[6] Torres-Coronas, T. (2015). Students and employers perception about the development of digital skills in higher education Percepción de estudiantes y empleadores sobre el desarrollo de competencias digitales en la Educación Superior. Revista de educación no 367. January-March 2015, 367, 63-89.

[7] Margaryan, A., Littlejohn, A., \& Vojt, G. (2011). Are digital natives a myth or reality? University students' use of digital technologies. Computers \& education, 56(2), 429-440.

[8] Beetham, H., Newman, T.\& Knight, N. (2018). Digital experience insights survey 2018: findings from Australian and New Zealand university students. JISC. Online available from: http://repository.jisc.ac.uk/7202/1/digital-e xperience-insights-survey-anz-2018.pdf.

[9] Wilson, K. B., Tete-Mensah, I., \& Boateng, K. A. (2014). Information and communication technology use in higher education: Perspectives from students. European Scientific Journal, 10(19). 
[10] Beetham, H., \& Sharpe, R. (2013). An introduction to rethinking pedagogy. In Rethinking pedagogy for a digital age (pp. 25-36). Routledge.

[11] Bradley, C. \& Holley, D. (2013). Empirical research into students' mobile phones and their use for learning.In Innovations in Mobile Educational Technologies and Applications, IGI Global, 318-333.

[12] Dahlstrom, E., \& Bichsel, J. (2014). ECAR Study of Undergraduate Students and Information Technology, 2014. Educause.

[13] Newman, T., \& Beetham, H. (2017). Student digital experience tracker 2017: the voice of 22,000 UK learners. Bristol: Jisc.

[14] Chen, B., \& Denoyelles, A. (2013). Exploring students' mobile learning practices in higher education. Educause Review, 7.

[15] Peña-López, I. (2015). Students, computers and learning. Making the connection. PISA, OECD Publishing, Paris, September 15.

[16] Jewitt.. K (2012). Technology Solutions for Student Learning: Research Study into the experiences and expectations of digital technology by students at PROCAT, Online available from: http://procatdigital.co.uk/technolog y-solutions-for-student-learning/.

[17] Galanek, J. D., Gierdowski, D. C., \& Brooks, D. C. (2018). ECAR Study of Undergraduate Students and Information Technology (Vol. 12, p. 12). 2018.

[18] Porter, G., Hampshire, K., Milner, J., Munthali, A., Robson, E., De Lannoy, A., ... \& Abane, A. (2016). Mobile Phones and education in Sub - Saharan Africa: from youth practice to public policy. Journal of International Development, 28(1), 22-39.

[19] Asabere, N. Y., Enguah, S. E., \& Mends-Brew, E. (2012). A Survey of Educational Expectations of Students: Mobile Device Usage in Tertiary Education In Ghana. Growth, 9.

[20] Mahamud, Z. I., Andrews, F. K., \& Rockson, A. K. (2015). Use of Mobile Phones to Support Coursework: Evidence from Wa Polytechnic, Ghana. Ghana Journal of Development Studies, 12(1-2), 195-207.

[21] Becker, S. A., Pasquini, L. A., \& Zentner, A. (2017). 2017 Digital Literacy Impact Study: An NMC Horizon Project Strategic Brief (pp. 1-24). The New Media Consortium.

[22] Addah. J (2012) Proficiency in Information Communication Technology and its Use: A Survey among Clinical Students in a Ghanaian Medical School. International Journal of Computer Applications 1, 45, 14-20.

[23] Gyamfi, S. A., \& Ryberg, T. (2012, October). Introducing Blended eLearning Course Design: A Pre-Implementation Assessment of Students' Basic ICT Skills. In European Conference on e-Learning (pp. 214-219). Academic Conferences and Publishing International.

[24] JISC (2017). Building digital capability, Online available from: https://www.JISC.ac.uk/rd/projects/building-digitalcapability.

[25] Quaicoe, J. S., Pata, K., \& Jeladze, E. (2016, July). Digital learning ecosystem services and educational change in
Ghana's basic schools. In 8th Annual International Conference on Education and New Learning Technologies,(Spain), EDULEARN16 Proceedings, 4th (pp. 4887-4895).

[26] Bohannon, J. L., Arnett, E. J., \& Greer, E. (2017, July). Learning Information Literacy across the Curriculum (LILAC) and its impacts on student digital literacies and learning across the humanities. In 2017 IEEE International Professional Communication Conference (ProComm) (pp. 1-8). IEEE.

[27] Bolstad, R. (2015). Zooming in on learning in the digital age (ZILDA): Report 1: Zooming in on'digital'age learners. Journal issue, (3).

[28] Price - Dennis, D., Holmes, K. A., \& Smith, E. (2015). Exploring digital literacy practices in an inclusive classroom. The ReadingTeacher, 69(2), 195-205.

[29] JISC (2015). A key role for universities and colleges Quick guide - Developing students' digital literacy. Online available from: https://digitalcapability.jiscinvolve.org/wp/ files/2014/09/JISC_REPORT_Digital_Literacies_280714_ PRINT.pdf.

[30] Selwyn, N., \& Facer, K. (2007). Beyond the digital divide: Rethinking digital inclusion for the 21 st century. Futurelab.

[31] Joshi, A., Kale, S., Chandel, S., \& Pal, D. K. (2015). Likert scale: Explored and explained. British Journal of Applied Science \& Technology, 7(4), 396.

[32] Anane-Boakye, S. (2016). Comparative Analysis: Successes and Failures of St. Louis Public Schools' Virtual Learning (Doctoral dissertation, Walden University). 